\title{
Technical and Economic Viability of Corn with Azospirillum brasilense Associated with Acidity Correctives and Nitrogen
}

\author{
Fernando S. Galindo ${ }^{1}$, Marcelo C. M. Teixeira Filho ${ }^{1}$, Salatiér Buzetti ${ }^{1}$, Willian L. Rodrigues ${ }^{1}$, \\ Eduardo H. M. Boleta ${ }^{1}$, Poliana A. L. Rosa ${ }^{1}$, Rafaela N. Gaspareto ${ }^{1}$, Antonio L. C. Biagini ${ }^{1}$, \\ Eduardo B. Baratella ${ }^{1} \&$ Ingrid T. Pereira ${ }^{1}$ \\ ${ }^{1}$ Department of Plant Health, Rural Engineering, and Soils, College of Engineering, Sao Paulo State University \\ (UNESP), Ilha Solteira, SP, Brazil \\ Correspondence: Fernando S. Galindo, Department of Plant Health, Rural Engineering, and Soils, College of \\ Engineering, Sao Paulo State University (UNESP), Ilha Solteira, SP, Brazil. Tel: 55-(18)-98120-8054. E-mail: \\ fs.galindo@yahoo.com.br
}

$\begin{array}{ll}\text { Received: December 12, } 2017 & \text { Accepted: January 15, } 2018 \quad \text { Online Published: February 15, } 2018 \\ \text { doi:10.5539/jas.v10n3p213 } & \text { URL: https://doi.org/10.5539/jas.v10n3p213 }\end{array}$

The research is financed by Fundação de Amparo à Pesquisa do Estado de São Paulo-FAPESP, process number 2017/06002-6.

\begin{abstract}
There is a lack of more comprehensive research defining how much mineral $\mathrm{N}$ can be applied as regards the efficiency of BNF to attain high with Azospirillum brasilense, what is a bacterium that stands out for its biological nitrogen fixation (BNF) in corn crops, reaching economically sustainable yields. Moreover, it would be interesting to investigate the use of silicon, which exerts numerous benefits on grasses, especially when the plants are subjected to biotic and abiotic stresses. The aim of this work was to study a synergistic effect between the inoculation with A. brasilense and the application of silicon, thus enabling a higher efficiency of nitrogen fertilization, evaluating the grain yield of irrigated corn in economic terms. The experiment was conducted in Selvíria, MS, Brazil, under a no-till system, on a Latossolo Vermelho distrófico (Oxisol). The experiment was set up as a randomized block design with four replications, in a $2 \times 5 \times 2$ factorial arrangement consisting of two soil corrective sources (dolomitic limestone and $\mathrm{Ca}$ and $\mathrm{Mg}$ silicate as source of $\mathrm{Si}$ ); five doses of $\mathrm{N}(0,50,100$, 150 and $200 \mathrm{~kg} \mathrm{ha}^{-1}$ ); with and without inoculation with A. brasilense. The inoculation makes the corn increase much more profitable, irrespective of $\mathrm{N}$ doses and corrective source. The $\mathrm{N}$ dose of $200 \mathrm{~kg} \mathrm{ha}^{-1}$ with dolomitic limestone, associated with inoculation provided greater grain yield. However, the highest economic return was obtained at the $\mathrm{N}$ dose of $100 \mathrm{~kg} \mathrm{ha}^{-1}$, with dolomitic limestone application and inoculation.
\end{abstract}

Keywords: Zea mays, biological nitrogen fixation in grasses, plant growth promoting bacteria, silicon application, total operational cost

\section{Introduction}

In order to obtain high corn grain yield it is necessary to apply high doses of nitrogen $(\mathrm{N})$, because the soils, in general, do not supply the demand of the crop during its cycle (Teixeira Filho et al., 2014; Galindo et al., 2016). Nitrogen fertilization is one of the highest costs of the production process of non-leguminous crops (Nunes et al., 2015). Wheat, corn, and rice crops utilize approximately $60 \%$ of the $\mathrm{N}$ fertilizer produced in the world (Espindula et al., 2014). Also both nitrogen fertilizer production and application contribute to the emission of gases $\left(\mathrm{CO}_{2}\right.$ and $\left.\mathrm{NO}_{2}\right)$ that contribute to the increase of the greenhouse effect on Earth (Xu et al., 2012).

In this context, one possibility of increasing the efficiency of nitrogen fertilization due to the high cost of fertilizers and the awareness of a sustainable and less polluting agriculture, is the use of inoculants containing bacteria that promote growth and increase plant productivity. The technology of inoculation of non-legumes with non-symbiotic plant growth-promoting bacteria (PGPB), whose main representative is Azospirillum spp. is also being increasingly adopted in several countries, especially for crops such as corn and wheat (Díaz-Zorita \& Fernandez-Canigia, 2009; Hartmann \& Bashan, 2009; Marks et al., 2015). The analysis of results from a large number of field trials with various non-legume crops, conducted worldwide over 20 years, under different soil 
and weather conditions, has demonstrated that yield increases of up to $30 \%$ could be obtained $70 \%$ of the time (Fukami et al., 2016; Fukami et al., 2017) in response to inoculation with Azospirillum.

Another practice that exerts numerous benefits on grasses is the use of silicon ( $\mathrm{Si}$ ) in agriculture, especially when the plants are submitted to biotic and abiotic stresses, common in adverse edaphoclimatic conditions such as in the Brazilian Cerrado. In addition, $\mathrm{Ca}$ and $\mathrm{Mg}$ silicate, besides correcting the acidity, raise the levels of soluble phosphorus, calcium, magnesium and silicon and, consequently, saturation by bases, reducing the toxic effect of iron, manganese and aluminum (Reis et al., 2008; Camargo et al., 2014a, 2014b). Si can also stimulate plant growth and yield through the formation of upright leaves and better plant architecture which increase the photosynthetic rate, with consequent reduction of bedding due to the greater structural rigidity of the tissues, and still presents another important benefit related to reduction in the transpiration rate (Reis et al., 2008; Camargo et al., 2014a, 2014b). When accumulating in the cells of the epidermal layer the Si can be a stable physical barrier in the penetration of some types of fungi, mainly in grasses.

However, in the majority of the investigations both with inoculation with Azospirillum brasilense and with $\mathrm{Si}$ as $\mathrm{Ca}$ and $\mathrm{Mg}$ silicate, although one or more of the previously reported benefits have been verified, the increase in corn yield was not always observed. In view of above, and due to the lack of information about this interaction, the hypothesis of this study was that there may be a synergic effect between inoculation with A. brasilense and silicon application, thus allowing a higher efficiency of nitrogen fertilization. Therefore, the objective of this work was to evaluate the effect of doses of nitrogen associated to the inoculation with Azospirillum brasilense and application of $\mathrm{Si}$, in the form of a corrective acidity on corn grain yield and economic analysis in Brazilian Cerrado.

\section{Methods}

\subsection{Field Sites and Material Description}

The experiment was conducted during the crop years of 2015/16 and 2016/17, located in Selvíria, MS, Brazil (335 m above sea level). The soil of the experimental area was classified as a Latossolo Vermelho distrófico (Oxisol) of clayey texture, according to Embrapa (2013), which had been cultivated with annual crops for over 28 years, with the last 11 years under the no-till system, and the crops prior to corn were corn and wheat, respectively. Precipitation, air relative humidity, and maximum, mean, and minimum temperatures recorded during the experimental period are shown in Figure 1. 

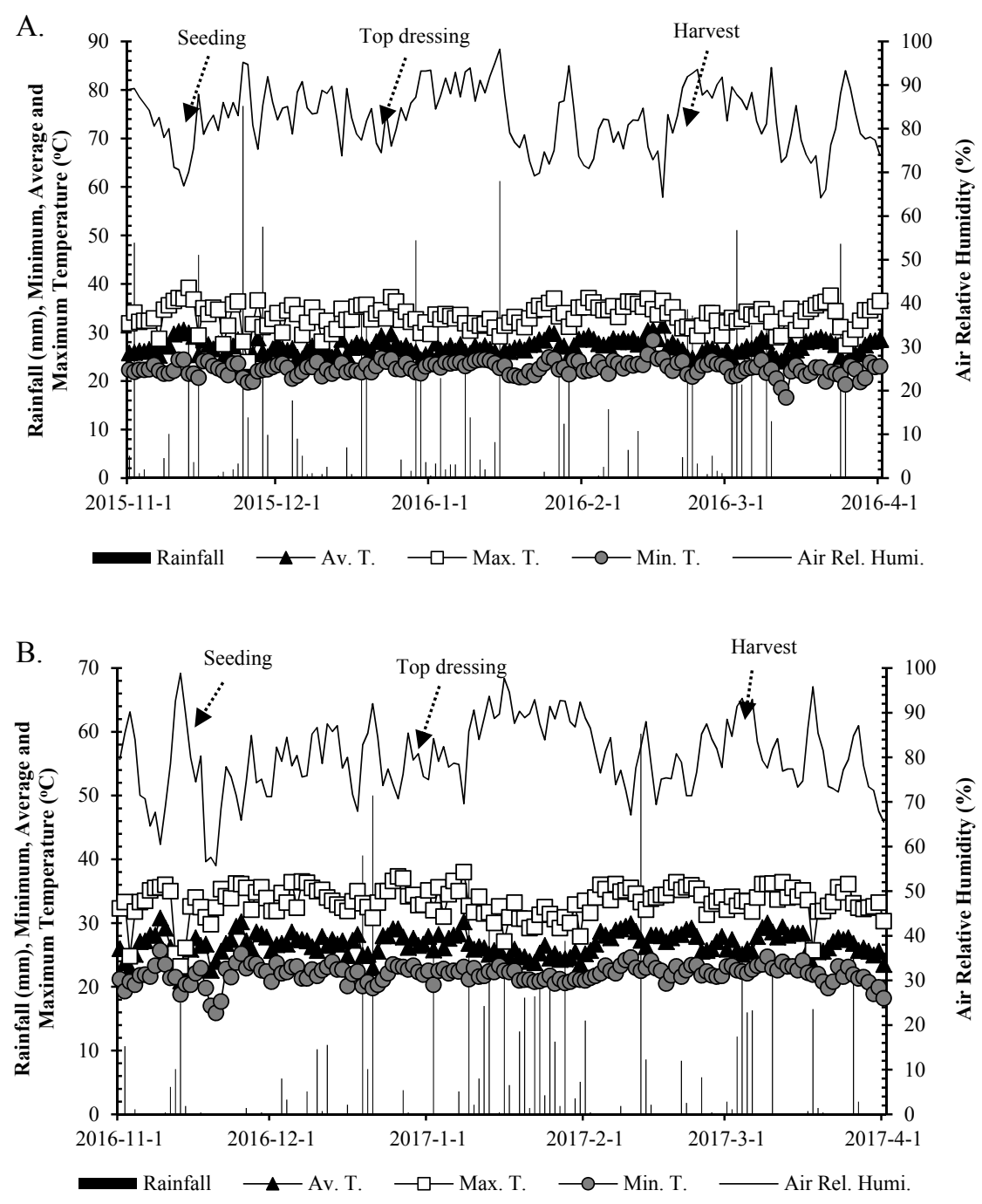

Figure 1. Rainfall, air relative humidity and maximum, average and minimum temperatures obtained from the weather station located in the Education and Research Farm of FE/UNESP during the corn cultivation in the period November 2015 to April 2016 (A) November 2016 to April 2017 (B)

\subsection{Experimental Design}

In both crops, a randomized-block design with four replications was set up in a $2 \times 5 \times 2$ factorial arrangement consisting of two soil corrective sources (dolomitic limestone PRNT $=80 \%, \mathrm{CaO}=28 \%$ and $\mathrm{MgO}=20 \%$ and silicate of $\mathrm{Ca}$ and $\mathrm{Mg}$ as Si source PRNT $=88 \%, \mathrm{Ca}=25 \%, \mathrm{Mg}=6 \%$ and $\mathrm{Si}$ total $=10 \%)$; Five doses of N (0, $50,100,150$ and $200 \mathrm{~kg} \mathrm{ha}^{-1}$, in the form of urea) applied at top-dressing; with and without inoculation of the seeds with $A$. brasilense. The plots of the corn experiment had $5 \mathrm{~m}$ long with 6 lines spaced by $0.45 \mathrm{~m}$, the plot area being the 4 central rows, excluding $0.5 \mathrm{~m}$ from the extremities.

The herbicides glyphosate (1800 $\mathrm{g} \mathrm{ha}^{-1}$ of the active ingredient [a.i.]) and 2,4-D (670 $\mathrm{g} \mathrm{ha}^{-1}$ of the a.i.) were used for the desiccation of the agricultural area. The soil chemical attributes in the arable layer were determined before the implementation of the corn experiment in 2015, following the methodology proposed by Raij et al. (2001). The following results were obtained: in the 0-0.20 m layer: $9.4 \mathrm{mg} \mathrm{dm}^{-3} \mathrm{Si}, 19 \mathrm{mg} \mathrm{dm}^{-3} \mathrm{P}$ (resin); $10 \mathrm{mg}$ $\mathrm{dm}^{-3}$ of S-SO $; 21 \mathrm{~g} \mathrm{dm}^{-3}$ organic matter; $5.0 \mathrm{pH}\left(\mathrm{CaCl}_{2}\right) ; \mathrm{K}, \mathrm{Ca}, \mathrm{Mg}, \mathrm{H}+\mathrm{Al}$ and $\mathrm{Al}=2.1 ; 19.0 ; 13.0 ; 28.0$ and $1.0 \mathrm{mmol}_{\mathrm{c}} \mathrm{dm}^{-3}$, respectively; $\mathrm{Cu}, \mathrm{Fe}, \mathrm{Mn}, \mathrm{Zn}(\mathrm{DTPA})=3.1 ; 20.0 ; 27.2$ and $0.8 \mathrm{mg} \mathrm{dm}^{-3}$, respectively; $0.17 \mathrm{mg}$ $\mathrm{dm}^{-3} \mathrm{~B}$ (hot water) and 55\% base saturation; and in the $0.20-0.40 \mathrm{~m}$ layer: $10.2 \mathrm{mg} \mathrm{dm}^{-3} \mathrm{Si}, 17 \mathrm{mg} \mathrm{dm}^{-3} \mathrm{P}$ (resin); $30 \mathrm{mg} \mathrm{dm}^{-3}$ of $\mathrm{S}_{-} \mathrm{SO}_{4} ; 16 \mathrm{~g} \mathrm{dm}^{-3}$ organic matter; $4.8 \mathrm{pH}\left(\mathrm{CaCl}_{2}\right) ; \mathrm{K}, \mathrm{Ca}, \mathrm{Mg}, \mathrm{H}+\mathrm{Al}$ and $\mathrm{Al}=1.2 ; 11.0 ; 8.0 ; 28.0$ 
and $2.0 \mathrm{mmol}_{\mathrm{c}} \mathrm{dm}^{-3}$, respectively; $\mathrm{Cu}, \mathrm{Fe}, \mathrm{Mn}, \mathrm{Zn}(\mathrm{DTPA})=2.1 ; 10.0 ; 10.7$ and $0.2 \mathrm{mg} \mathrm{dm}{ }^{-3}$, respectively; 0.11 $\mathrm{mg} \mathrm{dm}{ }^{-3} \mathrm{~B}$ (hot water) and $42 \%$ base saturation.

Based on the soil analysis and with the aim of increasing the saturation by bases to $80 \%$, the dose of $1.94 \mathrm{tha}^{-1}$ of dolomitic limestone and $1.76 \mathrm{t} \mathrm{ha}^{-1}$ of calcium and magnesium silicate was applied 30 days before sowing of corn, as top-dressing and without incorporation. During fertilization at planting, for both crop years of the experiment, $375 \mathrm{~kg} \mathrm{ha}^{-1}$ of the 08-28-16 formulation were used, corresponding to $30 \mathrm{~kg} \mathrm{ha}^{-1} \mathrm{~N}, 105 \mathrm{~kg} \mathrm{ha}^{-1} \mathrm{P}_{2} \mathrm{O}_{5}$, and $60 \mathrm{~kg} \mathrm{ha}^{-1} \mathrm{~K}_{2} \mathrm{O}$, based on the soil analysis and the requirements of the corn crop.

The inoculation of corn seeds with the bacterium Azospirillum brasilense strains Ab-V5 Ab-V6 (guaranteee of 2 $\times 10^{8} \mathrm{UFC} / \mathrm{mL}$-Inoculants consisted of a mixture of strains CNPSo 2083 (= Ab-V5) and CNPSo 2084 (= Ab-V6) of A. brasilense from the Collection of Diazotrophic and Plant Growth-Promoting Bacteria of Embrapa Soja, WFCC \# 1213, WDCM \# 1054) was carried out at the dose of $300 \mathrm{~mL}$ of inoculant (liquid) per hectare of planted seeds, with the aid of a clean mixer for incorporation in the seeds and was carried out one hour before sowing the crop and after treatment of the seeds with insecticide and fungicide. For seed treatment, the fungicides pyraclostrobin + thiophanate-methyl $(6 \mathrm{~g}+56 \mathrm{~g}$ of a.i. per $100 \mathrm{~kg}$ of seed) and the insecticide fipronil (62 $\mathrm{g}$ of a.i. per $100 \mathrm{~kg}$ of seed) were used.

The mechanical sowing of the simple hybrid DOW 2B710 PW was carried out on 11/13/15 in the 2015/16 crop and 11/11/16 in the 2016/17 crop, being sown 3.3 seeds per meter and emergence of seedlings five days after sowing, on 11/18/2015 and 11/16/2016, respectively. The corn crop was irrigated using a center pivot sprinkling system, with a mean water depth of $14 \mathrm{~mm}$ and an irrigation interval of approximately $72 \mathrm{~h}$. The herbicide tembotrione ( $84 \mathrm{~g} \mathrm{ha}^{-1}$ of a.i.) and atrazine $\left(1000 \mathrm{~g} \mathrm{ha}^{-1}\right.$ of a.i.) were applied for the control of post-emergence weeds, plus the addition of an adjuvant in the herbicide syrup, oil (720 $\mathrm{g} \mathrm{ha}^{-1}$ of a.i.), on 12/04/2015 and $12 / 02 / 2016$, respectively. Insect control was performed with methomyl $\left(215 \mathrm{~g} \mathrm{ha}^{-1}\right.$ a.i. $)$ and triflumurom $(24 \mathrm{~g}$ ha $^{-1}$ a.i.), on 12/20/2015 and 12/17/2016, respectively.

Nitrogen cover fertilization (treatments) was applied on hauls and without soil incorporation, between the corn lines, on 12/13/15 and 12/10/16 when the plants were with six leaves completely unfolded (V6). The application was done manually, distributing the fertilizer on the soil surface (without incorporation), to the side and approximately $10 \mathrm{~cm}$ of the rows, in order to avoid the contact of the fertilizer with the plants. The harvest was carried out on 03/15/2016 and 03/21/2017, that is, at 117 and 125 days after corn emergence, respectively. After cover fertilization, the area was irrigated by sprinkling (depth of $14 \mathrm{~mm}$ ) at night to minimize losses by volatilization of ammonia.

\subsection{Analytical Procedures}

Grain yield was determined by collecting the plants contained in the usable area of each plot. After mechanical harvesting, kernels were quantified and data were transformed into $\mathrm{kg} \mathrm{ha}^{-1}$ and corrected for $13 \%$ moisture (wet basis) and transformed into 60-kg sacks. Results were subjected to analysis of variance and Tukey's test at 5\% probability for comparison of means of acidity correctives sources and use or non-use of inoculation with Azospirillum brasilense, and adjusted to regression equations for the effect of $\mathrm{N}$ doses, on SISVAR software.

For the economic analysis, the structure based on the total operating production costs (TOC) used by the Institute of Agricultural Economics (IEA) was adopted, according to Matsunaga et al. (1976), consisting of the sum of operating expenses: operations performed, inputs (fertilizers, seeds, pesticides, etc.), labor, machinery, and irrigation, named effective operating costs (EOC). In this study, besides the TOC, other operating expenses and interests were included, considering 5\% of the EOC (Matsunaga et al., 1976), thus resulting in the total operating cost (TOC), which was extrapolated to one hectare. This methodology has been already used in several studies on economic evaluation in crops such as Kaneko et al. (2010), Garcia et al. (2012), and Galindo et al. (2017).

To determine the profitability of the involved treatments, profitability analyses were carried out following Martin et al. (1998). To this end, the following variables were determined: gross revenue (GR) (in R\$), as the product of the amount produced (in number of 60-kg sacks) by the average sale price (in $\mathrm{R} \$$ ); operating profit (OP), as the difference between the gross revenue and total operating cost; accumulated operating profit (AOP), as the sum of the OP obtained in the two years of study; profitability index (PI), understood as the ratio between operating profit (OP) and the net revenue (NR), in percent; equilibrium price, given a certain total operating production cost, as a the minimum price calculated to cover this cost, considering the average productivity of the producer; equilibrium yield, given a certain total operating production cost, as the minimum productivity to cover this cost, considering the average price paid to the producer. 
The average prices were quoted in the region of Selvíria, MS, Brazil, in 2017 (average of three years ago 2015, 2016 and 2017, according to IEA, 2017). In this study, simulations were performed as if each experimental treatment represented commercial crops. To help elaborate the data, especially concerning the machine-hour rate, the machine yield, the inputs utilized, and the price of the sack of corn, the grain producers of the region were interviewed, considering the prices paid for the inputs for the 2016/2017 crop. To facilitate the discussion, the values referring to the yields were transformed into $60-\mathrm{kg}$ sacks, which was the basic unit of sale by local producers. The cost of the sack of corn for the municipality of Selvíria (average of three years ago) was R $\$ 28.63$ per unit produced. As regards the acidity correctives sources, the price paid by the farmer was $\mathrm{R} \$ 85.00$ and $\mathrm{R} \$ 115.00$ per ton for dolomitic limestone and $\mathrm{Ca}$ and $\mathrm{Mg}$ silicate in the region, respectively. For the inoculum with Azospirillum brasilense, the expenditure was around $\mathrm{R} \$ 10.00$ per dose, and three doses were used per hectare in both corn crops.

\section{Results and Discussion}

\subsection{Technical Analysis: Corn Grain Yield}

Table 1 shows the corn grain yield data for the 2015/2016 and 2016/2017 crops as a function of the soil corrective sources and $\mathrm{N}$ doses with or without inoculation with $A$. brasilense.

Table 1. Corn grain yield affected by sources of soil acidity correctives, doses of nitrogen, with or without inoculation with Azospirillum brasilense. Selvíria MS, Brazil, 2015/16 and 2016/17

\begin{tabular}{llc}
\hline & \multicolumn{2}{c}{ Grain Yield $\left(60 \mathrm{~kg} \mathrm{sack} \mathrm{ha}{ }^{-1}\right)$} \\
\cline { 2 - 3 } & $2015 / 16$ & $2016 / 17$ \\
\hline Overall mean & 177.90 & 140.99 \\
C.V. $(\%)$ & 7.60 & 12.63 \\
\hline F test & & \\
DOSES & $39.091^{* *}$ & $37.134^{* *}$ \\
SOURCES & $0.041^{\mathrm{ns}}$ & $0.000^{\mathrm{ns}}$ \\
INOCULATION & $8.104^{* *}$ & $4.762^{*}$ \\
D $\times$ S & $9.050^{* *}$ & $8.474^{* *}$ \\
$\mathrm{D} \times \mathrm{I}$ & $9.189^{* *}$ & $8.157^{* *}$ \\
$\mathrm{~S} \times \mathrm{I}$ & $2.512^{\mathrm{ns}}$ & $0.987^{\mathrm{ns}}$ \\
$\mathrm{D} \times \mathrm{S} \times \mathrm{I}$ & $1.944^{\mathrm{ns}}$ & $0.437^{\mathrm{ns}}$ \\
\hline
\end{tabular}

Note. ${ }^{*}, *$ and ns: significant at $\mathrm{p}<0.01,0.01<\mathrm{p}<0.05$, and not significant, respectively. 

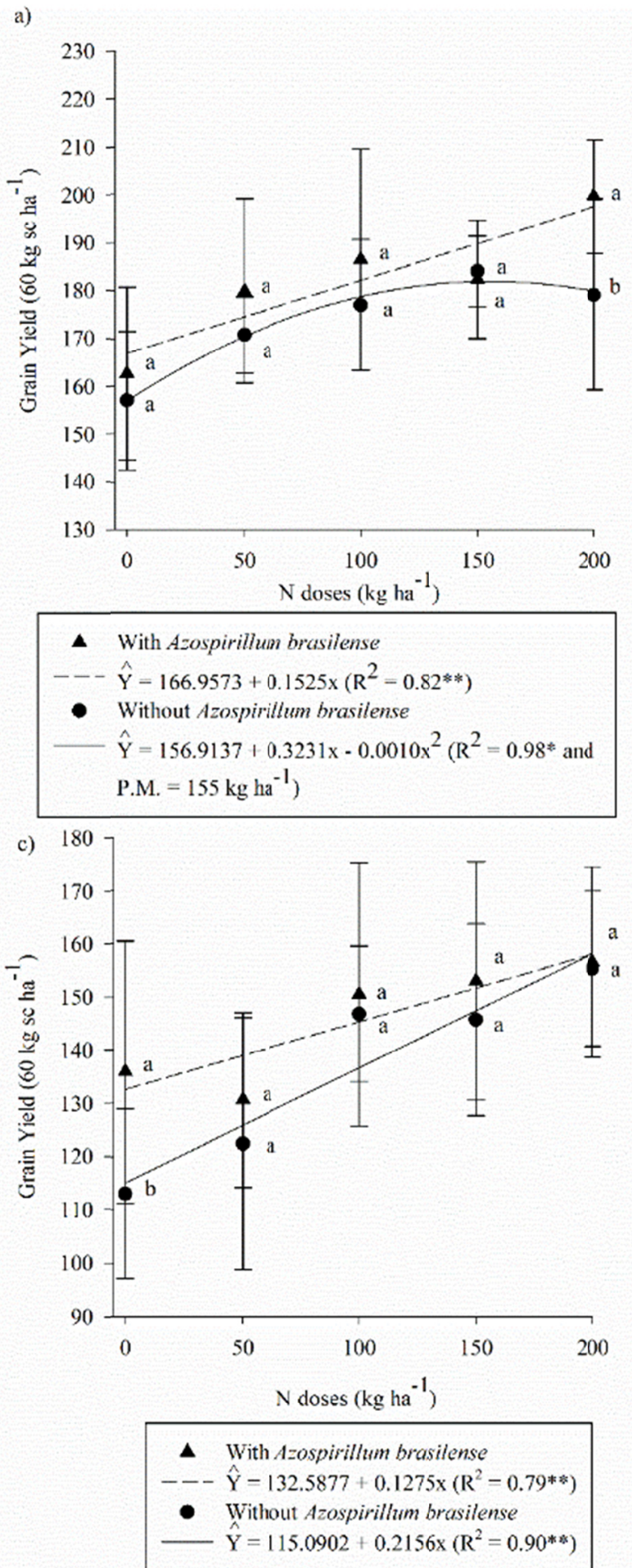

b)

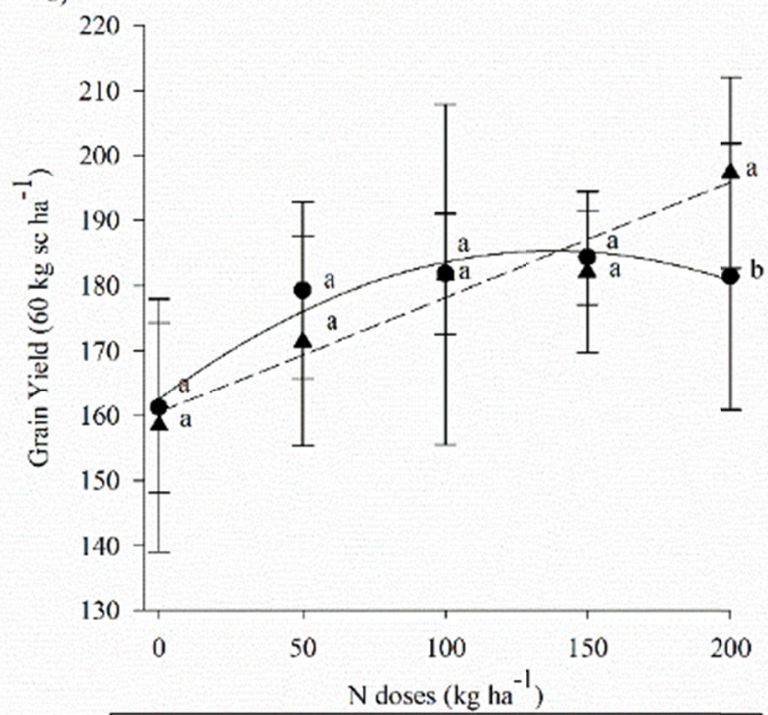

- Dolomitic limestone

$---\hat{\mathrm{Y}}=160.5512+0.1766 \times\left(\mathrm{R}^{2}=0.94^{* *}\right)$

- $\mathrm{Ca}$ and $\mathrm{Mg}$ silicate $\hat{\mathrm{Y}}=162.5529+0.3297 \mathrm{x}-0.0012 \mathrm{x}^{2}\left(\mathrm{R}^{2}=0.95^{*}\right.$ and P.M. $=138 \mathrm{~kg} \mathrm{ha}^{-1}$ )

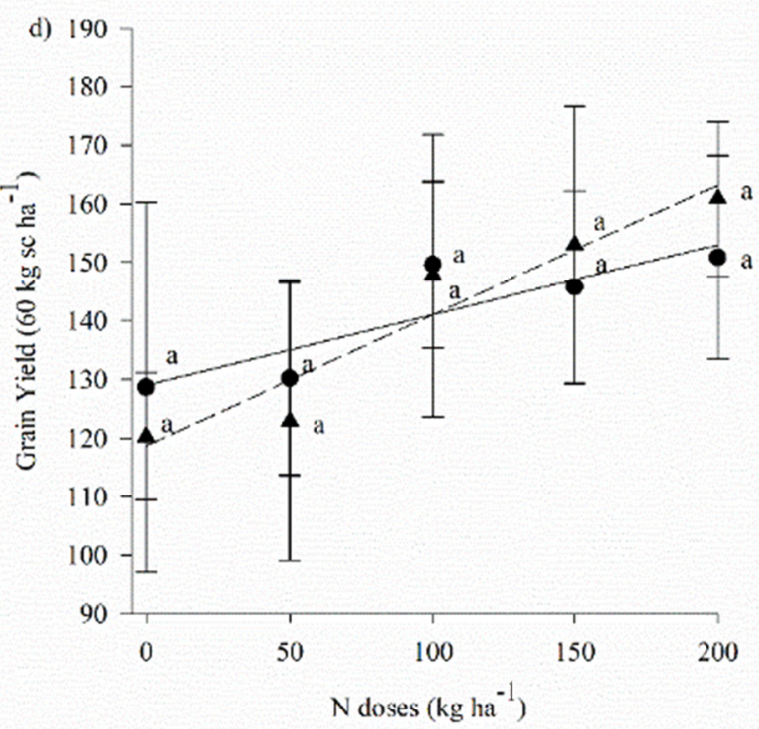

- Dolomitic limestone $\hat{\mathrm{Y}}=118.6963+0.2228 \times\left(\mathrm{R}^{2}=0.92 * *\right)$

- $\mathrm{Ca}$ and $\mathrm{Mg}$ silicate $\hat{\mathrm{Y}}=128.9816+0.1202 \times\left(\mathrm{R}^{2}=0.78^{* *}\right)$

Figure 1. Interaction between nitrogen doses and inoculation with Azospirillum brasilense on corn grain yield in (a) 2015/2016 and (c) 2016/2017, and interaction between nitrogen doses and sources of soil acidity correctives on corn grain yield in (b) 2015/2016 and (d) 2016/2017. Selvíria, MS, Brazil, 2015/2016 and 2016/2017

Note. The letters correspond to a significant difference at $5 \%$ probability level $(\mathrm{p} \leq 0.05)$. ** and *: significant at $\mathrm{p}<0.01$ and $0.01<\mathrm{p}<0.05$, respectively. Error bars indicate the standard error of the mean $(n=4)$.

The interaction between doses and inoculation was significant in both crops. In the 15/16 crop, at a dose of 200 $\mathrm{kg} \mathrm{ha}^{-1}$ of $\mathrm{N}$ applied in top-dressing, the use of Azospirillum brasilense resulted in higher grain yield compared to 
non-inoculated treatments (Figure 2). The yield increase at this dose with inoculation was approximately 21 bags of $60 \mathrm{~kg} \mathrm{ha}^{-1}$, equivalent to an increase of $11.4 \%$. There was adjustment to the increasing linear function for the inoculated treatments and adjustment to the quadratic function for the non-inoculated treatments until the dose of $155 \mathrm{~kg} \mathrm{ha}^{-1}$ of $\mathrm{N}$. The increase in yield of the control $\mathrm{N}$ dose $\left(0 \mathrm{~kg} \mathrm{ha}^{-1}\right)$ up to the dose that provided the maximum yield obtained with and without inoculation of the seeds with A. brasilense was 37 and 26 bags of 60 $\mathrm{kg} \mathrm{ha}^{-1}$, an increase equivalent to 22.7 and $16.5 \%$, respectively (Figure 2).

In the $16 / 17$ crop, in the absence of nitrogen fertilization $\left(0 \mathrm{~kg} \mathrm{ha}^{-1}\right.$ of $\left.\mathrm{N}\right)$, treatments inoculated with $A$. brasilense provided higher grain yield as compared to non-inoculated treatments, with a $20.2 \%$ increase in yield, equivalent to approximately 23 bags of $60 \mathrm{~kg} \mathrm{ha}^{-1}$ (Figure 2). There was an adjustment to the increasing linear function for the treatments inoculated and not inoculated with $A$. brasilense, with yield increase in absence of nitrogen fertilization until the dose that reached the maximum productivity in approximately 21 and 42 bags of $60 \mathrm{~kg} \mathrm{ha}^{-1}$, equivalent to 15.2 and $37.4 \%$, respectively, for treatments inoculated with A. brasilense and not inoculated (Figure 2).

In several studies, increases in corn grain yield are reported with the application of $\mathrm{N}$ doses in the cover (Kappes et al., 2013; Kappes et al., 2014; Galindo et al., 2016), einforcing the results obtained. Meira et al. (2009) observed that $\mathrm{NH}_{3}$ volatilization losses among the various fertilizers, including urea, did not reflect corn yield. Thus, the highest yields of grains were obtained when $\mathrm{N}$ was supplied in larger doses at the time of the cover, that is, there was $\mathrm{N}$ available in the soil solution in the period in which the plant requires higher amounts of the nutrient. An explanation would probably be due to the fact that the $\mathrm{N}$ applied at sowing is already in the soil solution and, when $\mathrm{N}$ is added, the plant has a larger amount of the element to be absorbed.

The results obtained demonstrate a positive effect of inoculation with Azospirillum brasilense on corn in both crops, and it is important to note that considering only the effect of inoculation alone, independently of the applied $\mathrm{N}$ dose and corrective source, the increase in yield by the use of this bacterium via seed was approximately 9 bags of $60 \mathrm{~kg} \mathrm{ha}^{-1}$ in both crops, corresponding to an increase in yield of 5 and $6 \%$. Similarly, Galindo et al. (2016), studying $\mathrm{N}$ doses in top-dressing (0, 50, 100, 150 and $200 \mathrm{~kg} \mathrm{ha}^{-1}$ ) with and without inoculation with $A$. brasilense verified increase in grain yield as a function of inoculation compared to non-inoculated treatments in 2013/14 and 2014/15 crops, respectively, with increase of 727 and $1298 \mathrm{~kg} \mathrm{ha}^{-1}$, corresponding to increase in bags of $60 \mathrm{~kg} \mathrm{ha}^{-1}$ in 12 and 22 bags, equivalent to 8.5 and $22.9 \%$.

Positive results with the use of Azospirillum were also reported by Kappes et al (2013), working with doses of $\mathrm{N}$ and inoculation with $A$. brasilense in corn in the first harvest. According to the authors, inoculation resulted in a 9.4\% increase in grain yield. Similar results were obtained by Novalkowiski et al. (2011), where corn yields were higher with inoculation of $A$. brasilense when compared to control, even with the increase of $\mathrm{N}$ applied. Hungria et al. (2010) also obtained increases in corn yield, and depending on the strain of $A$. brasilense evaluated, the increase in productivity was of the order of 24 to $30 \%$, corresponding to 662 to $823 \mathrm{~kg} \mathrm{ha}^{-1}$. The analysis of results from a large number of field trials with various non-legume crops, conducted worldwide over 20 years, under different soil and weather conditions, has demonstrated that yield increases of up to $30 \%$ could be obtained 70\% of the time (Fukami et al., 2016; Fukami et al., 2017) in response to inoculation with Azospirillum.

These increases are commonly attributed to root growth promotion, accomplished by phytohormones produced by the bacterium, with an emphasis on indole acetic acid, gibberellins and cytokinins (Tien et al., 1979). Moreover, it is inferred that the application of Azospirillum is also responsible for higher rates of absorption of water and minerals by the plant (Dardanelli et al., 2008) and higher tolerance to abiotic stresses, such as drought and salinity (Zawonski et al., 2011). The relationship between different soil microorganisms and the role of metabolites secreted by them on growth of other surrounding microbial species and plants has been the subject of numerous studies (Marks et al., 2015; Fukami et al., 2016; Fukami et al., 2017), and according to Bashan and de-Bashan (2010), due to the wide array of mechanisms proposed for stimulation of plant growth by Azospirillum spp., probably this bacteria promoves multiple mechanisms that might act either in a cumulative or sequential pattern.

Despite the increase in corn grain yield, the effects on grasses are very variable, and according to Novakowiski et al. (2011), it is difficult to elaborate an accurate recommendation on the use of these inoculants in corn crop due to this fact. It is of fundamental importance to take into account that the interaction between genotype of the plant with efficient strains of bacteria is the key fact for the success of biological N fixation (Lana et al., 2012) in addition to the environmental conditions (Hungria et al., 2010).

The interaction between doses and corrective sources was also significant in both crops. In the 2015/2016 harvest, at the dose of $200 \mathrm{~kg} \mathrm{ha}^{-1}$ of $\mathrm{N}$, the use of dolomitic limestone resulted in higher grain yields compared 
to $\mathrm{Ca}$ and $\mathrm{Mg}$ silicate (Figure 2). The increase in yield in this dose mentioned above with the use of limestone was approximately 16 bags of $60 \mathrm{~kg} \mathrm{ha}^{-1}$, equivalent to an increase of $8.8 \%$. There was adjustment to the increasing linear function for the treatments with limestone application and adjustment to the quadratic function until the dose of $138 \mathrm{~kg} \mathrm{ha}^{-1}$ of $\mathrm{N}$ for the treatments with silicate application. The increase in yield of the control dose of $\mathrm{N}$ up to the dose that provided the maximum productivity obtained with limestone and silicate was 39 and 24 bags of $60 \mathrm{~kg} \mathrm{ha}^{-1}$, an increase equivalent to 24.5 and 14.9\%, respectively (Figure 2).

In the $16 / 17$ crop, there was an adjustment to the increasing linear function for the treatments with limestone and $\mathrm{Ca}$ and $\mathrm{Mg}$ silicate, with increase of yield in the absence of nitrogen fertilization until the dose that reached the maximum productivity in approximately 41 and 22 bags of $60 \mathrm{~kg} \mathrm{ha}^{-1}$, equivalent to 33.9 and $17.4 \%$ respectively, for the treatments with application of limestone and $\mathrm{Ca}$ and $\mathrm{Mg}$ silicate (Figure 2).

In relation to the sources of correctives, isolated they provided similar and very close yield numerically, and although the gain in yield with the use of limestone was higher as a function of the increase of $\mathrm{N}$ doses, it is verified that the use of $\mathrm{Si}$ in the form of $\mathrm{Ca}$ and $\mathrm{Mg}$ silicate did not negatively affect inoculation with Azospirillum brasilense nor the efficiency of nitrogen fertilization.

The use of silicon $(\mathrm{Si})$ in agriculture exerts numerous benefits on grasses, especially when the plants are submitted to biotic and abiotic stresses, common in adverse edaphoclimatic conditions such as in the Brazilian Cerrado (Reis et al., 2008), but as ponder Camargo et al. (2014a, 2014b), this element will provide benefits mainly to the plants considered as accumulators, which include many grasses such as rice and sugar cane and contains concentration of $\mathrm{SiO}_{2}$ above 4\% (Lima et al., 2011), and that some factors will influence the uptake of Si by plants, such as genotype, type of soil and plant species, which could explain the slight response of the use of $\mathrm{Si}$ in the form of $\mathrm{Ca}$ and $\mathrm{Mg}$ silicate in corn crop in the present work further elucidating the importance of new silicon studies in potentially accumulating crops such as corn in Brazilian Cerrado.

3.2 Economic Analysis: Total Operating Costs, Gross Revenue, Operating Profit, Profitability Index, Accumulated Operating Profit, Equilibrium Price and Equilibrium Yield

Table 2 shows the structure of the total operating costs (TOC) of the corn crop in the municipality of Selviria, describing the treatment with dolomitc limestone, nitrogen dose of $0 \mathrm{~kg} \mathrm{ha}^{-1}$, without inoculation. This TOC structure model was used in all treatments. 
Table 2. Total operating costs structure model of corn for the treatment control (zero kg ha ${ }^{-1} \mathrm{~N}$ in top-dressing), with limestone application and without inoculation with A. brasilense per hectare. Selviria, MS, 2015/16 and 2016/17

\begin{tabular}{|c|c|c|c|c|c|}
\hline Description & Specification $^{1}$ & Times & Coefficient & Unitary Value $(\mathrm{R} \$)$ & Total Value $(\mathrm{R} \$)$ \\
\hline \multicolumn{6}{|l|}{ A. OPERATIONS } \\
\hline Soil acidity correctives application & $\mathrm{HM}$ & 1.00 & 0.30 & 85.00 & 25.50 \\
\hline Desiccation & $\mathrm{HM}$ & 1.00 & 0.50 & 85.00 & 42.50 \\
\hline Hoeing (triton) & $\mathrm{HM}$ & 1.00 & 0.50 & 85.00 & 42.50 \\
\hline Seeding & $\mathrm{HM}$ & 1.00 & 1.00 & 110.00 & 110.00 \\
\hline Pulverization & $\mathrm{HM}$ & 2.00 & 0.60 & 85.00 & 102.00 \\
\hline Top-dressing & $\mathrm{HM}$ & 1.00 & 0.50 & 85.00 & 42.50 \\
\hline Harvest & HM & 1.00 & 0.60 & 118.00 & 70.80 \\
\hline Irrigation (pivot) & $\mathrm{mm}$ & 1.00 & 120.00 & 2.50 & 300.00 \\
\hline Subtotal A & & & & & 735.80 \\
\hline \multicolumn{6}{|l|}{ B - AGRICULTURAL INPUT } \\
\hline Dolomitic limestone & $\mathrm{t}$ & 1.00 & 0.49 & 85.00 & 41.23 \\
\hline Fertilizer 08-28-16 & $\mathrm{t}$ & 1.00 & 0.38 & $1,998.00$ & 749.25 \\
\hline Urea & $\mathrm{t}$ & 1.00 & 0.00 & $1,750.00$ & 0.00 \\
\hline Inoculant (A. brasilense) & $\mathrm{L}$ & 1.00 & 0.00 & 10.00 & 0.00 \\
\hline Corn seed DOW 2B710 PW & sc $20 \mathrm{~kg}$ & 1.00 & 1.22 & 500.00 & 610.00 \\
\hline Glyphosate & $\mathrm{L}$ & 1.00 & 4.00 & 14.51 & 58.04 \\
\hline $2,4-\mathrm{D}$ & $\mathrm{L}$ & 1.00 & 1.00 & 13.24 & 13.24 \\
\hline Tembotrione & $\mathrm{L}$ & 1.00 & 0.20 & 403.21 & 80.64 \\
\hline Atrazine & $\mathrm{L}$ & 1.00 & 2.00 & 14.48 & 28.96 \\
\hline Vegetable oil adjuvant & $\mathrm{L}$ & 1.00 & 0.78 & 8.41 & 6.56 \\
\hline Metomyl & $\mathrm{L}$ & 1.00 & 1.00 & 20.59 & 20.59 \\
\hline Triflumuron & $\mathrm{L}$ & 1.00 & 0.05 & 203.19 & 10.16 \\
\hline $\begin{array}{l}\text { Seed treatment pyraclostrobin }+ \\
\text { thiophanate-methyl }+ \text { fipronil }\end{array}$ & $\mathrm{L}$ & 1.00 & 0.05 & 350.00 & 17.50 \\
\hline Subtotal B & & & & & $1,636.17$ \\
\hline Effective operating costs (EOC) & & & & $2,371.97$ & \\
\hline Other expenses & & & & 118.60 & \\
\hline Interest cost & & & & 77.09 & \\
\hline Total operating cost (TOC) & & & & $2,567.65$ & \\
\hline
\end{tabular}

Note. $\mathrm{HM}=$ Hour machine; $\mathrm{sc}=$ sack; 2016 and 2017 average exchange rate: $\mathrm{R} \$ 3.32=\mathrm{U} \$ 1.00$.

As can be seen in Table 2, the expenses with fertilizers, followed by mechanized operations, were the highest, corresponding to 30.8 and $28.7 \%$ of the TOC, respectively. This outcome is in line with Kaneko et al. (2010), who studied the viability of the corn crop for the northeast region of São Paulo State in the 2007/2008 and 2008/2009 crops in a no-till system and $\mathrm{N}$ management up to the dose of $120 \mathrm{~kg} \mathrm{ha}^{-1}$ and found higher expenditures with fertilizers and mechanized operations, corresponding to 32.74 and $30.91 \%$ TOC, with yields ranging from 85.9 and 146.1 sacks $^{-1}{ }^{-1}$.

Similar results to those obtained by Galindo et al. (2017), working with the viability of the corn crop for Brazilian Cerrado region in 2013/2014 and 2014/2015 crops with doses and sources of $\mathrm{N}(0,50,100,150$ and $200 \mathrm{~kg} \mathrm{ha}^{-1}$, with the sources urea and urea with NBPT), with and without inoculation with Azospirillum brasilense who found higher expenditures with fertilizers and mechanized operations, corresponding to 31.3 and $28.9 \%$ TOC, with yields ranging from 92.6 and 153.6 sacks ha $^{-1}$. It should point out that with the elevation of $\mathrm{N}$ doses and change of analyzed acidity corrective source, the percentage of expenses in relation to the TOC of the fertilizers tends to increase. Garcia et al. (2012) worked with the corn crop in the region of Selvíria, with different intercrops with forages, and had higher expenses related to corn seeds inputs $(46.46 \%)$, followed by costs with fertilization (39.01\%) and greater operating costs with irrigation via center pivot (45.28\%), with yields varying from 105 to 137 sacks of $60 \mathrm{~kg}$ of corn, using urea as the source at the $\mathrm{N}$ dose of $100 \mathrm{~kg} \mathrm{ha}^{-1}$.

The costs with nitrogen top-dressing, as a function of the increasing $\mathrm{N}$ doses, ranged from 9.2 to $23.9 \%$ of the TOC. Working with $\mathrm{N}$ doses $\left(0,45,90,135\right.$, and $180 \mathrm{~kg} \mathrm{ha}^{-1}$ as top-dressing) with and without inoculation with 
A. brasilense, Kaneko et al. (2015) had costs with fertilization at planting in the first and second crops of 31.80 and $24.16 \%$ of the TOC, respectively, with yields ranging from 119 to 191 sacks of $60 \mathrm{~kg}$ of corn. Galindo et al. (2017) working with $\mathrm{N}$ doses $\left(0,50,100,150\right.$ and $\left.200 \mathrm{~kg} \mathrm{ha}^{-1}\right)$ with and without inoculation with $A$. brasilense had costs with fertilization at planting ranged from 7.6 to $24.8 \%$ of the TOC as a function of the increasing $\mathrm{N}$ doses. For the costs with correctives application, values ranged, in both crops, between 1.9 and 2.6 and 2.1 and $2.9 \%$ with the dolomitc limestone and $\mathrm{Ca}$ and $\mathrm{Mg}$ silicate, respectively.

As regards the TOC and yield of the treatments (Table 3), the highest value for the former was found in the treatment with $\mathrm{Ca}$ and $\mathrm{Mg}$ silicate and the $\mathrm{N}$ dose of $200 \mathrm{~kg} \mathrm{ha}^{-1}$ plus inoculation with $\mathrm{A}$. brasilense. The lowest TOC corresponded to the treatments with dolomitic limestone application, without nitrogen top-dressing $(0 \mathrm{~kg}$ $\mathrm{ha}^{-1}$ ) and without inoculation with $A$. brasilense. However, it is noteworthy that if $\mathrm{N}$ is not replenished in the soil, the soil reserves deplete as the nutrient is extracted, which compromises the productivity of crops over time. For grain yield, the highest values were found in the treatment with dolomitic limestone at the $\mathrm{N}$ dose of $200 \mathrm{~kg} \mathrm{ha}^{-1}$ plus inoculation with $A$. brasilense in the 2015/16 crop, and with dolomitic limestone at the $\mathrm{N}$ dose of $200 \mathrm{~kg}$ $\mathrm{ha}^{-1}$ without inoculation with $A$. brasilense in the $2015 / 16 \mathrm{crop}$, with average yields of 208.33 and 164.08 sacks of $60 \mathrm{~kg}$, respectively.

Table 3. Total operating cost, grain yield and gross revenue of corn affected by sources of soil acidity correctives, doses of nitrogen, with or without inoculation with Azospirillum brasilense. Selvíria, MS, 2015/16 and 2016/17

\begin{tabular}{|c|c|c|c|c|c|c|c|c|c|c|}
\hline \multicolumn{11}{|c|}{ Without Azospirillum brasilense } \\
\hline \multirow{3}{*}{ Doses } & \multicolumn{5}{|c|}{ Limestone } & \multicolumn{5}{|c|}{$\mathrm{Ca}$ and $\mathrm{Mg}$ Silicate } \\
\hline & \multirow{2}{*}{ TOC } & \multicolumn{2}{|c|}{ YIELD } & \multicolumn{2}{|c|}{ GR } & \multirow{2}{*}{ TOC } & \multicolumn{2}{|c|}{ YIELD } & \multicolumn{2}{|c|}{ GR } \\
\hline & & $2015 / 16$ & $2016 / 17$ & $2015 / 16$ & $2016 / 17$ & & $2015 / 16$ & $2016 / 17$ & $2015 / 16$ & $2016 / 17$ \\
\hline & -- R\$ -- & \multicolumn{2}{|c|}{--- $60 \mathrm{~kg} \mathrm{ha}^{-1} \mathrm{sc}---$} & \multicolumn{2}{|c|}{-------- RS --------- } & -- R\$ -- & \multicolumn{2}{|c|}{--- $60 \mathrm{~kg} \mathrm{ha}^{-1} \mathrm{sc}---$} & \multicolumn{2}{|c|}{------ R\$ -------- } \\
\hline 0 & 2567.65 & 147.98 & 120.02 & 4236.76 & 3436.17 & 2577.80 & 166.12 & 106.07 & 4755.98 & 3036.65 \\
\hline 50 & 2778.14 & 163.75 & 125.17 & 4688.16 & 3583.53 & 2788.29 & 177.85 & 119.65 & 5091.74 & 3425.65 \\
\hline 100 & 2988.63 & 167.85 & 151.32 & 4805.62 & 4332.30 & 2998.78 & 186.12 & 142.29 & 5328.52 & 4073.63 \\
\hline 150 & 3199.11 & 185.13 & 158.31 & 5300.26 & 4532.31 & 3209.26 & 182.96 & 133.08 & 5238.01 & 3809.98 \\
\hline 200 & 3409.60 & 186.35 & 164.08 & 5335.19 & 4697.54 & 3419.75 & 171.91 & 146.52 & 4921.64 & 4194.84 \\
\hline Mean & 2988.63 & 170.21 & 143.78 & 4873.20 & 4116.37 & 2998.78 & 176.99 & 129.52 & 5067.18 & 3708.15 \\
\hline \multicolumn{11}{|c|}{ With Azospirillum brasilense } \\
\hline \multirow{3}{*}{ Doses } & \multicolumn{5}{|c|}{ Limestone } & \multicolumn{5}{|c|}{$\mathrm{Ca}$ and $\mathrm{Mg}$ Silicate } \\
\hline & \multirow{2}{*}{ TOC } & \multicolumn{2}{|c|}{ YIELD } & \multicolumn{2}{|c|}{ GR } & & \multicolumn{2}{|c|}{ YIELD } & \multicolumn{2}{|c|}{ GR } \\
\hline & & $2015 / 16$ & $2016 / 17$ & $2015 / 16$ & $2016 / 17$ & 10 & $2015 / 16$ & $2016 / 17$ & $2015 / 16$ & $2016 / 17$ \\
\hline & -- RS -- & \multicolumn{2}{|c|}{--- $60 \mathrm{~kg} \mathrm{ha}^{-1} \mathrm{sc}---$} & \multicolumn{2}{|c|}{------- R\$ -------- } & -- RS -- & \multicolumn{2}{|c|}{--- $60 \mathrm{~kg} \mathrm{ha}^{-1} \mathrm{sc}---$} & \multicolumn{2}{|c|}{-------- R\$ --------- } \\
\hline 0 & 2600.13 & 169.03 & 120.58 & 4839.22 & 3452.26 & 2610.28 & 156.49 & 151.22 & 4480.21 & 4329.32 \\
\hline 50 & 2810.62 & 179.15 & 120.70 & 5128.94 & 3455.56 & 2820.76 & 180.68 & 140.63 & 5172,89 & 4026.29 \\
\hline 100 & 3021.1 & 195.52 & 144.10 & 5597.74 & 4125.65 & 3031.25 & 177.45 & 156.90 & 5080.28 & 4492.17 \\
\hline 150 & 3231.59 & 179.01 & 147.62 & 5124.96 & 4226.40 & 3241.74 & 185.63 & 158.42 & 5314.60 & 4535.67 \\
\hline 200 & 3442.07 & 208.33 & 157.92 & 5964.51 & 4521.11 & 3452.22 & 190.90 & 155.27 & 5465.57 & 4445.28 \\
\hline Mean & 3021.10 & 186.21 & 138.18 & 5331.07 & 3956.20 & 3031.25 & 178.23 & 152.49 & 5085.17 & 4365.75 \\
\hline
\end{tabular}

Note. * Average corn trading price R $\$ 28,63$ per 60-kg sack according to IEA (2017).

As to the gross revenues per hectare (Table 3) obtained in the combination of treatments, in both studied harvests, the price of corn being constant, the gross revenues of the treatments followed the same trend as the yields (Table 3); that is, the accruals in revenue are due to the increases in grain yield. This result is in agreement with Duete et al. (2009), according to whom the yield is a primordial factor to ensure good profitability to the producer. As asserted by Duete et al. (2009), even in regions where producers obtain good corn prices, if their productivity is low, profitability is compromised. Thus, investment in management practices, like balanced nitrogen fertilization, elevates the grain yield and the gross margin of the corn crop, regardless of the location.

For the values referring to operating profit (Table 4), in both crops, the OP was positive for all studied treatments, irrespective of dose, source of acidity correctives, or inoculation, agreeing with the results obtained by Galindo 
et al. (2017), who obtained positive OP in 2013/2014 crop working with $\mathrm{N}$ doses and inoculation with Azospirillum brasilense in corn crop at Brazilian Cerrado.

Table 4. Operating profit and profitability index of corn affected by sources of soil acidity correctives, doses of nitrogen, with or without inoculation with Azospirillum brasilense. Selvíria, MS, 2015/16 and 2016/17

\begin{tabular}{|c|c|c|c|c|c|c|c|c|}
\hline \multicolumn{9}{|c|}{ Without Azospirillum brasilense } \\
\hline \multirow{3}{*}{ Doses } & \multicolumn{4}{|c|}{ Limestone } & \multicolumn{4}{|c|}{$\mathrm{Ca}$ and $\mathrm{Mg}$ Silicate } \\
\hline & \multicolumn{2}{|c|}{ OP } & \multicolumn{2}{|c|}{ PI } & \multicolumn{2}{|c|}{ OP } & \multicolumn{2}{|c|}{ PI } \\
\hline & $2015 / 16$ & $2016 / 17$ & $2015 / 16$ & $2016 / 17$ & $2015 / 16$ & $2016 / 17$ & $2015 / 16$ & $2016 / 17$ \\
\hline & \multicolumn{2}{|c|}{---------- R\$ ---------- } & \multicolumn{2}{|c|}{ 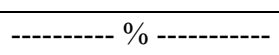 } & \multicolumn{2}{|c|}{---------- R\$ ---------- } & \multicolumn{2}{|c|}{--------- \% --------- } \\
\hline 0 & 1669.11 & 868.52 & 39.40 & 25.28 & 2178.18 & 458.85 & 45.80 & 15.11 \\
\hline 50 & 1910.02 & 805.39 & 40.74 & 22.47 & 2303.45 & 637.36 & 45.24 & 18.61 \\
\hline 100 & 1816.99 & 1343.67 & 37.81 & 31.02 & 2329.74 & 1074.85 & 43.72 & 26.39 \\
\hline 150 & 2101.15 & 1333.20 & 39.64 & 29.42 & 2028.75 & 600.72 & 38.73 & 15.77 \\
\hline 200 & 1925.59 & 1287.94 & 36.09 & 27.42 & 1501.89 & 775.09 & 30.52 & 18.48 \\
\hline Mean & 1884.57 & 1127.74 & 38.74 & 27.12 & 2068.40 & 709.37 & 40.80 & 18.87 \\
\hline \multicolumn{9}{|c|}{ With Azospirillum brasilense } \\
\hline \multirow{3}{*}{ Doses } & \multicolumn{4}{|c|}{ Limestone } & \multicolumn{4}{|c|}{$\mathrm{Ca}$ and $\mathrm{Mg}$ Silicate } \\
\hline & \multicolumn{2}{|c|}{$\mathrm{OP}$} & \multicolumn{2}{|c|}{ PI } & \multicolumn{2}{|c|}{ OP } & \multicolumn{2}{|c|}{ PI } \\
\hline & $2015 / 16$ & $2016 / 17$ & $2015 / 16$ & $2016 / 17$ & $2015 / 16$ & $2016 / 17$ & $2015 / 16$ & $2016 / 17$ \\
\hline & \multicolumn{2}{|c|}{---------- R\$ ---------- } & \multicolumn{2}{|c|}{--------- \% ---------- } & \multicolumn{2}{|c|}{---------- R\$ ---------' } & \multicolumn{2}{|c|}{--------- \% ---------. } \\
\hline 0 & 2239.09 & 852.13 & 46.27 & 24.68 & 1869.53 & 1719.04 & 41.74 & 39.71 \\
\hline 50 & 2318.32 & 644.94 & 45.20 & 18.66 & 2352.13 & 1205.53 & 45.47 & 29.94 \\
\hline 100 & 2576.64 & 1104.55 & 46.03 & 26.77 & 2049.03 & 1460.92 & 40.33 & 32.52 \\
\hline 150 & 1893.37 & 994.81 & 36.94 & 23.54 & 2072.86 & 1293.93 & 39.00 & 28.53 \\
\hline 200 & 2522.44 & 1079.04 & 42.29 & 23.87 & 2013.35 & 993.06 & 36.84 & 22.34 \\
\hline Mean & 2309.97 & 935.09 & 43.35 & 23.50 & 2071.38 & 1334.50 & 40.68 & 30.61 \\
\hline
\end{tabular}

In the 2015/16 crop, the highest OP was obtained using dolomitic limestone at the $\mathrm{N}$ dose of $100 \mathrm{~kg} \mathrm{ha}^{-1}$ plus inoculation with $A$. brasilense ( $\$ 2,576.64)$. For $2016 / 17$, the best result $(\mathrm{R} \$ 1,719.04)$ was obtained by using $\mathrm{Ca}$ and $\mathrm{Mg}$ silicate without $\mathrm{N}$ application in top-dressing $\left(0 \mathrm{~kg} \mathrm{ha}^{-1}\right)$ plus inoculation with A. brasilense (Table 4), and despite being the best outcome obtained in this harvest, it is still much lower than that found in the previous harvest. Even with nitrogen fertilization as top-dressing in high doses, which would increase costs, with the possibility of reducing the OP, corn growing would be viable, given mainly the high yield obtained; this reinforces the importance of nitrogen fertilization management so as to achieve high yields and consequently high financial return. Aguiar et al. (2008) found a positive effect of corn sold in April 2007, grown in a no-till system, without nitrogen fertilization, partially differing from what we obtained in this study. The same was reported by Kaneko et al. (2015), who obtained a profitability index without nitrogen fertilization, with and without inoculation, of 42.36 and $57.84 \%$, respectively.

Evaluating the OP balance of both harvests, in absence of inoculation, the treatments that provided the highest OP were those without $\mathrm{N}$ dose of $150 \mathrm{~kg} \mathrm{ha}^{-1}$ with dolomitic limestone application (Table 5), generating $\mathrm{R} \$ 3,434.35$. When the treatments were inoculated with A. brasilense, the highest $\mathrm{OP}$ was obtained at the $\mathrm{N}$ dose of $100 \mathrm{~kg} \mathrm{ha}^{-1}$, using dolomitic limestone, generating $\mathrm{R} \$ 3,681.19$. For the acidity correctives sources, the highest OP was obtained for the dolomitic limestone when the $\mathrm{N}$ dose of $100 \mathrm{~kg} \mathrm{ha}^{-1}$ was applied and with inoculation with $A$. brasilense, providing $\mathrm{R} \$ 3,681.19$, and for the $\mathrm{Ca}$ and $\mathrm{Mg}$ Silicate, the highest OP was obtained without application of $\mathrm{N}$ and with seed inoculation with $A$. brasilense, providing $\mathrm{R} \$ 3,588.57$ (Table 5). An expressive increase was observed in $\mathrm{OP}$ at the end of two years of cultivations, with inoculation with $A$. brasilense, making the corn crop more profitable, with a $7.19 \%$ increase from the highest OP without inoculation to the treatment that provided the highest OP with inoculation. In turn, Galindo et al. (2017), verified that the inoculation with Azospirillum brasilense associated with the $\mathrm{N}$ dose of $100 \mathrm{~kg} \mathrm{ha}^{-1}$ in top-dressing promote higher profitability with the corn crop in the Brazilian Cerrado. 
Table 5. Accumulated operating profit, equilibrium price and equilibrium yield of corn affected by sources of soil acidity correctives, doses of nitrogen, with or without inoculation with Azospirillum brasilense. Selvíria, MS, 2015/16 and 2016/17

\begin{tabular}{|c|c|c|c|c|c|c|c|c|}
\hline \multicolumn{9}{|c|}{ Without Azospirillum brasilense } \\
\hline \multirow{3}{*}{ Doses } & \multicolumn{4}{|c|}{ Limestone } & \multicolumn{4}{|c|}{$\mathrm{Ca}$ and $\mathrm{Mg}$ Silicate } \\
\hline & \multirow{2}{*}{ AOP } & \multicolumn{2}{|c|}{$\mathrm{EP}$} & \multirow{2}{*}{$\mathrm{EY}$} & \multirow{2}{*}{ AOP } & \multicolumn{2}{|c|}{$\mathrm{EP}$} & \multirow{2}{*}{ EY } \\
\hline & & $2015 / 16$ & $2016 / 17$ & & & $2015 / 16$ & $2016 / 17$ & \\
\hline & --- R\$ --- & \multicolumn{2}{|c|}{------ R R sc ${ }^{-1}$------- } & $60 \mathrm{~kg} \mathrm{ha}^{-1} \mathrm{sc}$ & --- R\$ --- & \multicolumn{2}{|c|}{------ R R sc ${ }^{-1}$------- } & $60 \mathrm{~kg} \mathrm{ha}^{-1} \mathrm{sc}$ \\
\hline 0 & 2537.63 & 17.35 & 21.39 & 89.68 & 2637.03 & 15.52 & 24.30 & 90.04 \\
\hline 50 & 2715.41 & 16.97 & 22.20 & 97.04 & 2940.81 & 15.68 & 23.30 & 97.39 \\
\hline 100 & 3160.66 & 17.81 & 19.75 & 104.39 & 3404.59 & 16.11 & 21.08 & 104.74 \\
\hline 150 & 3434.35 & 17.28 & 20.21 & 111.74 & 2629.47 & 17.54 & 24.12 & 112.09 \\
\hline 200 & 3213.53 & 18.30 & 20.78 & 119.09 & 2276.98 & 19.89 & 23.34 & 119.45 \\
\hline Mean & 3012.32 & 17.54 & 20.87 & 104.39 & 2777.78 & 16.95 & 23.23 & 104.74 \\
\hline \multicolumn{9}{|c|}{ With Azospirillum brasilense } \\
\hline \multirow{3}{*}{ Doses } & \multicolumn{4}{|c|}{ Limestone } & \multicolumn{4}{|c|}{$\mathrm{Ca}$ and $\mathrm{Mg}$ Silicate } \\
\hline & \multirow{2}{*}{ AOP } & \multicolumn{2}{|c|}{ EP } & \multirow{2}{*}{ EY } & \multirow{2}{*}{ AOP } & \multicolumn{2}{|c|}{ EP } & \multirow{2}{*}{ EY } \\
\hline & & $2015 / 16$ & $2016 / 17$ & & & $2015 / 16$ & $2016 / 17$ & \\
\hline & --- R\$ --- & \multicolumn{2}{|c|}{------- R\$ sc ${ }^{-1}$} & $60 \mathrm{~kg} \mathrm{ha}^{-1} \mathrm{sc}$ & --- R\$ --- & \multicolumn{2}{|c|}{------- R\$ sc ${ }^{-1}$} & $60 \mathrm{~kg} \mathrm{ha}^{-1} \mathrm{sc}$ \\
\hline 0 & 3091.22 & 15.38 & 21.56 & 90.82 & 3588.57 & 16.68 & 17.26 & 91.17 \\
\hline 50 & 2963.26 & 15.69 & 23.29 & 98.17 & 3557.66 & 15.61 & 20.06 & 98.52 \\
\hline 100 & 3681.19 & 15.45 & 20.96 & 105.52 & 3509.95 & 17.08 & 19.32 & 105.88 \\
\hline 150 & 2888.18 & 18.05 & 21.89 & 112.87 & 3366.79 & 17.46 & 20.46 & 113.23 \\
\hline 200 & 3601.48 & 16.52 & 21.80 & 120.23 & 3006.41 & 18.08 & 22.23 & 120.58 \\
\hline Mean & 3245.07 & 16.22 & 21.90 & 105.52 & 3405.88 & 16.98 & 19.87 & 105.88 \\
\hline
\end{tabular}

With respect of profitability index, the highest value was obtained in 2015/16 crop, with the treatment with dolomitic limestone without N application with A. brasilense providing a PI of 46.27. For 2016/17 crop, application of $\mathrm{Ca}$ and $\mathrm{Mg}$ silicate without $\mathrm{N}$ application plus inoculation provided a PI of 35.71. Kaneko et al. (2015), obtained a average PI varying between 49.92 and 37.58, and 48.30 and 36.56 with urea source and without and with inoculation of $A$. brasilense, respectively, as a function of the $\mathrm{N}$ doses of $0,45,90,135$ and 180 $\mathrm{kg} \mathrm{ha}^{-1}$, and those values are near than those found in the present study.

In the analysis of equilibrium yield (minimum yield to cover the costs), for the price of $\mathrm{R} \$ 28.63$ per sack of 60 $\mathrm{kg}$ of corn, when $\mathrm{Ca}$ and $\mathrm{Mg}$ silicate was used at the $\mathrm{N}$ dose of $200 \mathrm{~kg} \mathrm{ha}^{-1}$ plus inoculation with $A$. brasilense, the equilibrium yield was higher (Table 5) - 120.58 sacks $\mathrm{ha}^{-1}$ - while the lowest equilibrium yields were observed without application of nitrogen fertilizer: 89.68 and 90.04 sacks ha $^{-1}$, to cover the costs of production without and with inoculation with $A$. brasilense, respectively.

Although the lowest equilibrium yield was obtained in absence of nitrogen fertilization, it is noteworthy that a lack of $\mathrm{N}$ supply in a cultivated soil will reduce its concentration in the soil, thus compromising the success of the activity over time, in case the nutrient is not replenished.

Very little variation was observed between non-inoculated and inoculated treatments with regard to equilibrium yield, at the same doses and soil acididty correctives sources applied, which is due to the low cost of the inoculum and of inoculation (R\$ 10.00 per dose), which is one of the main advantages of inoculation. For Kaneko et al. (2015), the average equilibrium yield ranged at approximated 79 sacks ha $^{-1}$ with application of urea without and with inoculation, respectively, at the $\mathrm{N}$ doses of $0,45,90,135$, and $180 \mathrm{~kg} \mathrm{ha}^{-1}$. However, it is worth mentioning that a great fluctuation of prices and yields in corn-producing regions as a function of the agricultural crops.

The values (in R\$) of the 60-kg corn sack for the equilibrium price (minimum price to cover the TOC) are shown in Table 5. The grains produced with the use of dolomitic limestone had a lower equilibrium price as compared with those produced using $\mathrm{Ca}$ and $\mathrm{Mg}$ silicate in both crops (average of $\mathrm{R} \$ 16.88$ and $\mathrm{R} \$ 21.4$ for limestone and $\mathrm{R} \$ 16.97$ and $\mathrm{R} \$ 21.6$ for silicate, respectively). Concerning the $\mathrm{N}$ doses, without $\mathrm{N}$ application in top-dressing provided lower equilibrium prices when associated with inoculation with $A$. brasilense: $\mathrm{R} \$ 15.45$ and $\mathrm{R} \$ 15.32$, in 
2015/16 and in 2016/17, with dolomitic limestone and $\mathrm{Ca}$ and Mg silicate respectively. By contrast, when the treatments with $\mathrm{Ca}$ and $\mathrm{Mg}$ silicate at the $\mathrm{N}$ dose of 200 and at $0 \mathrm{~kg} \mathrm{ha}^{-1} \mathrm{~N}$ were used, both without inoculation, in $2015 / 16$ and $2016 / 17$, respectively, the highest equilibrium prices were found: $\mathrm{R} \$ 19.89$ and $\mathrm{R} \$ 24.30$, respectively. For Kaneko et al. (2015), the average equilibrium price of the sack of corn ranged from $\mathrm{R} \$ 13.66$ to $\mathrm{R} \$ 16.86$ and $\mathrm{R} \$ 13.96$ to $\mathrm{R} \$ 17.13$ for the treatments with and without inoculation, respectively, as a function of $\mathrm{N}$ doses, values that are somewhat lower than those verified in the present work, but according to Galindo et al. (2017), the average equilibrium price of the sack of corn ranged from $R \$ 20.81$ to $R \$ 32.80$ and $R \$ 19.28$ to $\mathrm{R} \$ 26.61$ for the treatments with and without inoculation, respectively, as a function of $\mathrm{N}$ doses utilized, corroborating with the results obtained.

The results obtained demonstrate benefits in corn grain yield, elucidating the need for new research related to the beneficial effects of inoculation with $A$. brasilense associated with nitrogen fertilization and calling attention to the possibility of wide use of this technology in the field due to low economic cost, non-toxic and with high potential of response of corn crop, even with the application of $\mathrm{N}$ doses considered high for BNF. For this reason, this technique is likely increasingly adopted by rural farmers.

\section{Conclusions}

The use of silicon as $\mathrm{Ca}$ and $\mathrm{Mg}$ silicate source associated with inoculation with Azospirillum brasilense does not negatively affect the efficiency of nitrogen fertilization and corn grain yield.

Inoculation with Azospirillum brasilense makes corn increase more profitable, irrespective of the $\mathrm{N}$ dose and source of corrective.

Using $\mathrm{Ca}$ and $\mathrm{Mg}$ silicate is less interesting in economic terms. Therefore, we recommended to use dolomitic limestone, given its easy acquisition and greater economic return.

The $\mathrm{N}$ dose of $200 \mathrm{~kg} \mathrm{ha}^{-1}$ with dolomitic limestone, associated inoculation with Azospirillum brasilense, provides greater grain yields, but the highest economic return is obtained at the $\mathrm{N}$ dose of $100 \mathrm{~kg} \mathrm{ha}^{-1}$, with limestone and inoculation, ensuring profitability from production of irrigated corn in the Cerrado.

\section{References}

Aguiar, R. A. D., Silveira, P. M. D., Moreira, J. A. A., \& Wander, A. E. (2008). Análise econômica de diferentes práticas culturais na cultura do milho (Zea mays L.). Pesquisa Agropecuária Tropical, 38(4), 241-248.

Bashan, Y., \& de-Bashan, L. E. (2010). How the plant growth-promoting bacterium Azospirillum promotes plant growth-A critical assessment. Advances in Agronomy, 108, 77-136. https://doi.org/10.1016/S0065-2113 (10)08002-8

Camargo, M. S., Korndörfer, G. H., \& Foltran, D. E. (2014b). Absorção de silício e incidência de broca-do-colmo em duas soqueiras de variedades de cana-de-açúcar. Bioscience Journal, 30(5), 1304-1313.

Camargo, M. S., Korndörfer, G. H., \& Wyler, P. (2014a). Silicate fertilization of sugarcane cultivated in tropical soils. Field Crops Research, 167, 64-75. https://doi.org/10.1016/j.fcr.2014.07.009

Dardanelli, M. S., de Córdoba, F. J. F., Espuny, M. R., Carvajal, M. A. R., Díaz, M. E. S., Serrano, A. M. G., ... Megías, M. (2008). Effect of Azospirillum brasilense coinoculated with Rhizobium on Phaseolus vulgaris flavonoids and Nod Factor production under salt stress. Soil Biology and Biochemistry, 40(11), 2713-2721. https://doi.org/10.1016/j.soilbio.2008.06.016

Díaz-Zorita, M., \& Fernandez-Canigia, M. V. (2009). Field performance of a liquid formulation of Azospirillum brasilense on dryland wheat productivity. European Journal of Soil Biology, 45(1), 3-11. https://doi.org/ 10.1016/j.ejsobi.2008.07.001

Duete, R. R. C., Muraoka, T., Silva, E., Trevelin, P., \& Ambrosano, E. J. (2009). Viabilidade econômica de doses e parcelamentos da adubação nitrogenada na cultura do milho em Latossolo Vermelho Eutrófico. Acta Scientiarum. Agronomy, 31(1), 175-181. https://doi.org/10.4025/actasciagron.v31i1.6646

Empresa Brasileira de Pesquisa Agropecuária (Embrapa). (2013). Sistema Brasileiro de Classificação de Solos (3rd ed., p. 353). Brasília, DF: Embrapa, Centro Nacional de Pesquisa de Solos.

Espindula, M. C., Rocha, V. S., Souza, M. A. D., Campanharo, M., \& Pimentel, A. J. B. (2014). Urease inhibitor (NBPT) and efficiency of single or split application of urea in wheat crop. Revista Ceres, 61(2), 273-79. https://doi.org/10.1590/S0034-737X2014000200016

Fukami, J., Nogueira, M. A., Araujo, R. S., \& Hungria, M. (2016). Accessing inoculation methods of maize and wheat with Azospirillum brasilense. AMB Express, 6(1), 3-16. https://doi.org/10.1186/s13568-015-0171-y 
Fukami, J., Ollero, F. J., Megías, M., \& Hungria, M. (2017). Phytohormones and induction of plant-stress tolerance and defense genes by seed and foliar inoculation with Azospirillum brasilense cells and metabolites promote maize growth. AMB Express, 7(1), 153-163. https://doi.org/10.1186/s13568-0170453-7

Galindo, F. S., Teixeira Filho, M. C. M., Buzetti, S., Santini, J. M. K., Alves, C. J., Nogueira, L. M., ... Bellotte, J. L. M. (2016). Corn yield and foliar diagnosis affected by nitrogen fertilization and inoculation with Azospirillum brasilense. Revista Brasileira de Ciência do Solo, 40(1), e015036. https://doi.org/10.1590/ $18069657 \mathrm{rbcs} 20150364$

Galindo, F. S., Teixeira Filho, M. C. M., Tarsitano, M. A. A., Buzetti, S., Santini, J. M. K., Ludkiewicz, M. G. Z., ... Arf, O. (2017). Economic analysis of corn inoculated with Azospirillum brasilense associated with nitrogen sources and doses. Semina: Ciências Agrárias, 38(4), 1749-1764. https://doi.org/10.5433/ 1679-0359.2017v38n4p1749

Garcia, C. M. P., Andreotti, M., Tarsitano, M. A. A., Teixeira Filho, M. C. M., Lima, A. E. S., \& Buzetti, S. (2012). Análise econômica da produtividade de grãos de milho consorciado com forrageiras dos gêneros Brachiaria e Panicum em sistema plantio direto. Revista Ceres, 59(2), 157-163. https://doi.org/10.1590/ S0034-737X2012000200002

Hartmann, A., \& Bashan, Y. (2009). Ecology and application of Azospirillum and other plant growth-promoting bacteria (PGPB). European Journal of Soil Biology, 45(1), 1-2. https://doi.org/10.1016/j.ejsobi.2008.11.004

Hungria, M., Campo, R. J., Souza, E. M. S., \& Pedrosa, F. O. (2010). Inoculation with selected strains of Azospirillum brasilense and A. lipoferum improves yields of maize and wheat in Brazil. Plant and Soil, 331(1/2), 413-425. https://doi.org/10.1007/s11104-009-0262-0

Kaneko, F. H., Arf, O., Gitti, D. C., Tarsitano, M. A. A., Rapassi, R. M. A., \& Vilela, R. G. (2010). Custos e rentabilidade do milho em função do manejo do solo e da adubação nitrogenada. Pesquisa Agropecuária Tropical, 40(1), 102-109.

Kaneko, F. H., Sabundjian, M. T., Arf, O., Ferreira, J. P., Gitti, D. C., Nascimento, V., \& Leal, A. J. F. (2015). Análise econômica do milho em função da inoculação com Azospirillum, fontes e doses de $\mathrm{N}$ em cerrado de baixa altitude. Revista Brasileira de Milho e Sorgo, 14(1), 23-37. https://doi.org/10.18512/1980-6477/ rbms.v14n1p23-37

Kappes, C., Arf, O., Arf, M. V., Ferreira, J. P., Dal Bem, E. A., Portugal, J. R., \& Vilela, R. G. (2013). Inoculação de sementes com bactéria diazotrófica e aplicação de nitrogênio em cobertura e foliar em milho. Semina: Ciências Agrárias, 34(2), 527-538. https://doi.org/10.5433/1679-0359.2013v34n2p527

Kappes, C., Arf, O., Dal Bem, E. A., Portugal, J. R., \& Gonzaga, A. R. (2014). Manejo do nitrogênio em cobertura na cultura do milho em sistema plantio direto. Revista Brasileira de Milho e Sorgo, 13(2), 201-217. https://doi.org/10.18512/1980-6477/rbms.v13n2p201-217

Lana, M. C., Dartora, J., Marini, D., \& Hann, J. E. H. (2012). Inoculation with Azospirillum, associated with nitrogen fertilization in maize. Revista Ceres, 59(3), 399-405. https://doi.org/10.1590/S0034-737X2012 000300016

Lima, M. A., Castro, V. F., Vidal, J. B., \& Enéas-Filho, J. (2011). Aplicação de silício em milho e feijão-de-corda sob estresse salino. Revista Ciência Agronômica, 42(2), 398-403. https://doi.org/10.1590/S1806-669020110 00200019

Marks, B. B., Megías, M., Ollero, F. J., Nogueira, M. A., Araujo, R. S., \& Hungria, M. (2015). Maize growth promotion by inoculation with Azospirillum brasilense and metabolites of Rhizobium tropici enriched on lipo-chitooligosaccharides (LCOs). AMB Express, 5(1), 71-82. https://doi.org/10.1186/s13568-015-0154-z

Martin, N. B., Serra, R., Oliveira, M. D. M., Angelo, J. A., \& Okawa, H. (1998). Sistema integrado de custos agropecuários - “CUSTAGRI”. Informações Econômicas, 28(1), 7-28.

Matsunaga, M., Bemelmans, P. F., Toledo, P. E. N. de, Dulley, R. D., Okawa, H., \& Pedroso, I. A. (1976) Metodologia de custo de produção utilizada pelo IEA. Agricultura em São Paulo, 23(1), 123-139.

Meira, F. A., Buzetti, S., Andreotti, M., Arf, O., Sá, M. E., \& Andrade, J. A. C. (2009). Fontes e épocas de aplicação do nitrogênio na cultura do milho irrigado. Semina: Ciências Agrárias, 30(2), $275-284$. https://doi.org/10.5433/1679-0359.2009v30n2p275 
Novakowiski, J. H., Sandini, I. E., Falbo, M. K., Moraes, A., Novakowiski, J. H., \& Cheng, N. C. (2011). Efeito residual da adubação nitrogenada e inoculação de Azospirillum brasilense na cultura do milho. Semina: Ciências Agrárias, 32(4, S1), 1687-1698. https://doi.org/10.5433/1679-0359.2011v32n4Sup1p1687

Nunes, P. H. M. P., Aquino, L. A., Santos, L. P. D. D., Xavier, F. O., Dezordi, L. R., \& Assunção, N. S. (2015). Produtividade do trigo irrigado submetido à aplicação de nitrogênio e à inoculação com Azospirillum brasilense. Revista Brasileira de Ciência do Solo, 39(1), 174-182. https://doi.org/10.1590/01000683rbcs 20150354

Raij, B. van, Andrade, J. C., Cantarella, H., \& Quaggio, J. A. (2001). Análise química para avaliação da fertilidade de solos tropicais (p. 285). Campinas: IAC.

Reis, M. A. R., Arf, O., da Silva, M. G., de Sá, M. E., \& Buzetti, S. (2008). Aplicação de silício em arroz de terras altas irrigado por aspersão. Acta Scientiarum. Agronomy, 30(1), 37-43. https://doi.org/10.4025/ actasciagron.v30i1.1126

Teixeira Filho, M. C. M., Buzetti, S., Andreotti, M., Benett, C. G. S., Arf, O., \& Sá, M. E. (2014). Wheat nitrogen fertilization under no till on the low altitude Brazilian Cerrado. Journal of Plant Nutrition, 37(11), 1732-48. https://doi.org/10.1080/01904167.2014.889150

Tien, T. M., Gaskins, M. H., \& Hubbell, D. H. (1979). Plant growth substances produced by Azospirillum brasilense and their effect on the growth of pearl millet (Pennisetum americanum L.). Applied and Environmental Microbiology, 37(5), 1016-1029.

Xu, G., Fan, X., \& Miller, A. J. (2012). Plant nitrogen assimilation and use efficiency. Annual Review of Plant Biology, 63(1), 153-182. https://doi.org/10.1146/annurev-arplant-042811-105532

Zawonski, M. S., Ameneiros, M., Benavides, M. P., Vázquez, S., \& Groppa, M. D. (2011). Response to saline stress and aquaporin expression in Azospirillum-inoculated barley seedlings. Applied Microbiology and Biotechnology, 90(4), 1389-1397. https://doi.org/10.1007/s00253-011-3162-1

\section{Copyrights}

Copyright for this article is retained by the author(s), with first publication rights granted to the journal.

This is an open-access article distributed under the terms and conditions of the Creative Commons Attribution license (http://creativecommons.org/licenses/by/4.0/). 